\title{
Kodály’s Works for Piano: Comments on Technical Features and Historical Contexts
}

\author{
Thomas KABISCH \\ Staatliche Hochschule für Musik \\ Schultheiß-Koch-Platz 3, D-78647 Trossingen, Germany \\ E-mail:Th.Kabisch@t-online.de
}

(Received: November 2017; accepted: January 2018)

\begin{abstract}
There is a gap separating Kodály's Seven Pieces for Piano, op. 11 from his Nine Pieces for Piano, op. 3. The differences of style, structure, and texture cannot be explained in terms of development, let alone progress in any sense. With op. 11, Kodály undertakes a shift of paradigms from instrumental principles to a kind of vocal orientation within instrumental music. Op. 3 stands in the tradition of autonomous instrumental music, of Liszt and French music in particular, and displays similarities to early piano works by Bartók. In op. 11, that instrumental paradigm and its core principle of indirect expression are called into question. Instead Kodály aims at direct expression, vocality on the piano. Since a piano cannot sing, the pieces op. $11 \mathrm{can}$ be seen as failing in terms of Classical-Romantic composing standards. This paper argues that in dealing with the distinction between instrumental and vocal music, Kodály takes up a major topic of Musical Modernism (Carl Dahlhaus) and exposes himself deliberately to the risky question of "When is Art?" (Nelson Goodman).
\end{abstract}

Keywords: Kodály, works for piano, autonomous instrumental music, Musical Modernism

\section{Kodály and Musical Modernism}

Anna Dalos points in an excellent booklet text to a recording of Kodály's piano works to the difference between Kodály's view on music before and after 1923. ${ }^{1}$ She quotes Kodály's 1944 declaration “My parents were poor...” in which Kodály Records, 2008). 
espouses a kind of music education intimately linked to national education, resting on singing, and opposing bourgeois music culture, e.g. piano music. This rejection of piano and criticism of the bourgeois culture of instrumental music as idle entertainment shorn of deeper aim or meaning applies equally to Kodály's own past as a composer: it is self-criticism of a self-destructive kind. When in 1944 Kodály looked back on his early years, on the difference in his way of composing before and after 1923 and between vocal music and instrumental music, he saw an unbridgeable gap between two worlds of music, one for real people, one for mere amusement of abstract audiences.

Dalos's concise text restores the early piano pieces to their rights, defending them against Kodály's self-criticism. She points out how the piano pieces op. 3 and the op. 11 work and what fascination both of them exert on audiences, without being frivolous or shallow in any sense. She puts Kodály's piano music in a manifold context, to which contributions are made likewise by Bartók (his Fourteen Bagatelles, op. 6) and by French music, Debussy in particular, and by folk music and Western art music in general.

Taking Dalos's commentary as a point of departure, this paper argues there was a change in Kodály's view of music, his musical poetics, long before 1923, materialized in the difference between the op. 3 and op. 11 collections. Yes, both are piano music, but not instrumental in the same sense. In op. 11 Kodály wants the piano to sing, to address and move listeners directly, without mediation. To an extent he renounces the principle of indirect expression at the core of self-contained instrumental composition since the days of Hans Georg Nägeli and Ernst Theodor Amadeus Hoffmann. ${ }^{2}$ While the gap described by Kodály in 1944 concerns the difference between real singing and real instrumental performance, that between op. 11 and op. 3 is one of concepts, though one with real compositional consequences.

Such questioning of the fundamentals of autonomous instrumental music is typical of composers in the period between 1890 and 1914, dubbed "Musical Modernism" (Musikalische Moderne) by the late Carl Dahlhaus. ${ }^{3}$ Composers and writers on music of that time deal with isolated elements and aspects of the classical paradigm, straining them to the utmost at the expense of balance and integration into a whole. In doing so they expose themselves and their work to serious difficulties, raising the question "When is music?".

2.E. T. A. Hoffmann, Schriften zur Musik, hrsg. Friedrich Schnapp (München: Winkler s. d.), 118; Hans Georg Nägeli, Vorlesungen über Musik mit Berücksichtigung der Dilettanten (Stuttgart-Tübingen: J. G. Cotta, 1826; reprinted Darmstadt: Wissenschaftliche Buchgesellschaft, 1983).

3. See "Kapitel V: 1889-1914" in Carl Dahlhaus, Neues Handbuch der Musikwissenschaft, Bd. 6: Die Musik des 19. Jahrhunderts (Wiesbaden: Athenaion; Laaber: Laaber-Verlag, 1980), 218-276; English translation by J. Bradford Robinson as "Chapter Six 1889-1914," in Nineteenth-Century Music (Berkeley-Los Angeles-London: University of California Press, 1989), 330-389.

4. Cf. chapter IV: "When is Art?" in Nelson Goodman, Ways of Worldmaking (Indianapolis-Cambridge: Hackett 1978), 57-70. 
Kodály in op. 11 jeopardizes principles of instrumental composition that he had successfully incorporated into his op. 3. With the apparent vocal tendency in op. 11, he expresses doubts as to whether it is possible to find a balance or a mediation between "inflection" (Tonfall) and "logic" in self-contained instrumental music. This places him, in terms of his analytical and reflective way of composing, among all those seen by their contemporaries as exponents of Musical Modernism - from Strauss and Sibelius to Fauré, Reger, Schoenberg, and Scriabin.

A second topic addressed by Anna Dalos is treated here in more detail: Kodály's leaning toward French music, which culminated around 1907, but does not always work along the same lines. There are works that take up the challenge inherent in Debussy's poetics, and others that merely tend to an impressionistic style. Which reception prevails is connected and varies with Kodály's stand toward Liszt. Some pieces follow a Lisztian model while concurrently intimating French music. This dual strategy links with the tradition of non-discursive music. The second type, alluding merely to impressionistic style, does not connect with Liszt.

\section{Méditation}

An example is Kodály's Méditation sur un motif de Claude Debussy (1907). The musical narrative, or if you prefer, the musical drama rests on a Lisztian blueprint - an interrelation of melodic repetition and textural variants - and the music unfolds in a tripartite, Lisztian dramaturgy familiar from Liebestraum, for example. First comes an exposition of melodic, harmonic, and textural elements, then a middle section of repetition-transposition-amplification, leading to a dynamic climax, after which the music returns to its quiet initial constellation.

The main question here is whether the changes of register, the displacements inside the system of melody and accompaniment, and the altered dynamics affect the identical components in the music, which remain literally unchanged. Is there a reinterpretation (Umdeutung) of the identical? ${ }^{6}$ That is the question (see Example la).

In this case there is. When the listener gets to Più mosso (see Example 1b), the melodic elements that appear in the tenor and later the treble center on an ostinato of arpeggiated chords in the middle register. Are these chords an accompaniment? Yes, indeed. Are they nothing else? No, for the listener gains after a time an impression that the ostinato marks the intervallic substance that by the melodic lines is only projected into horizontal motion. The hierarchy is in reverse order. The emphasis lies on the accompaniment; the melodic elements, prominent at the outset of the piece, now are of a secondary effect.

5. Dahlhaus, Nineteenth-Century Music, 369.

6. Cf. Moritz Hauptmann's theory of cadence and his concept of dissonance, in Die Natur der Harmonik und der Metrik (Leipzig: Breitkopf und Härtel, 1853). 
Example 1a Kodály, Méditation, mm. 1-6

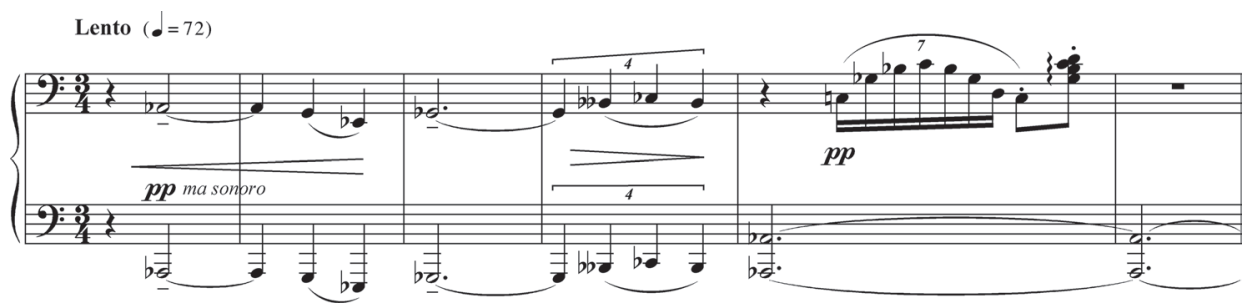

EXAMPLE 1b Kodály, Méditation, mm. 33-38
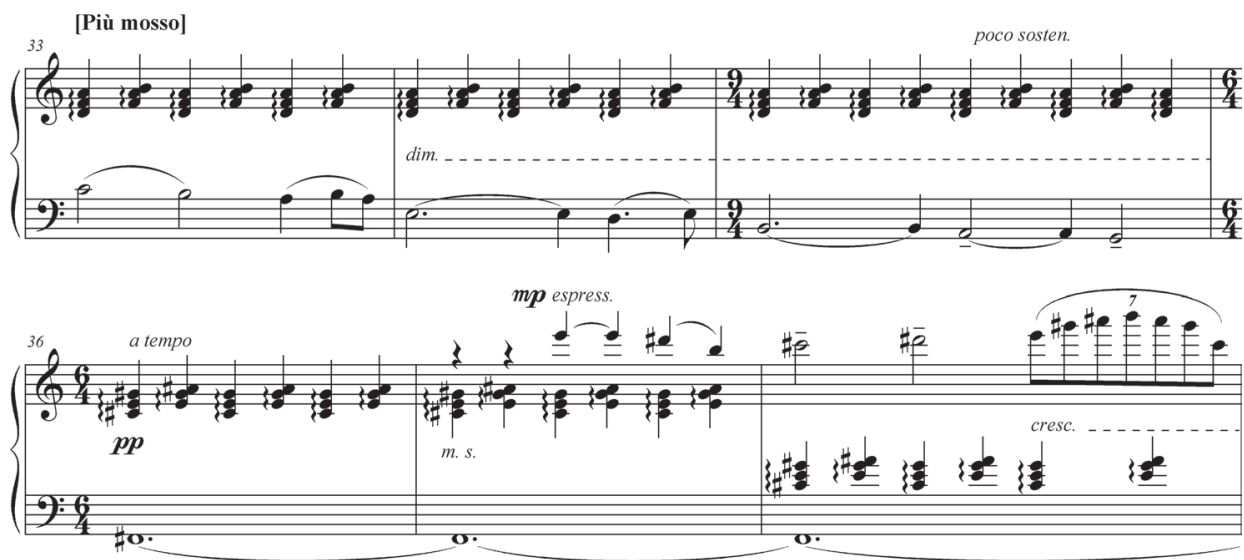

The Più Andante section (see Example 1c) begins with a configuration of melody and accompaniment: the melody is no longer the clear center or motor of the musical narrative. The multi-layered accompaniment fills up the tonal space, with a melodic line inserted. (The melody has no space exclusive to itself.) The move to the climax is not driven by melodic development, but by intensification and augmentation of the accompanying figuration. The melodic element reappears at the Con moto (see Example 1d) as a contour within the chord progression.

The piece is complex in the sense in which instrumental music is generally supposed to be so. It begins with a melodic Gestalt that is apparently the subject of the musical narrative, in a sense of a "theme." But the interplay between melodic gestures and accompanying figuration in the middle section leaves open whether there is a melodic subject at all to serve as a center to the narrative, let alone dominate it. The music is increasingly concerned with an intervallic cell that seems to be projected into the tonal space in two ways: vertically as well as in a horizontal line. So the subject of the musical process has become far more abstract and remote. The structure has taken over, and the sphere or field in which the intervallic structure produces its different effects is sound, not Gestalt. 
ExAmPLe 1c Kodály, Méditation, mm. 49-54
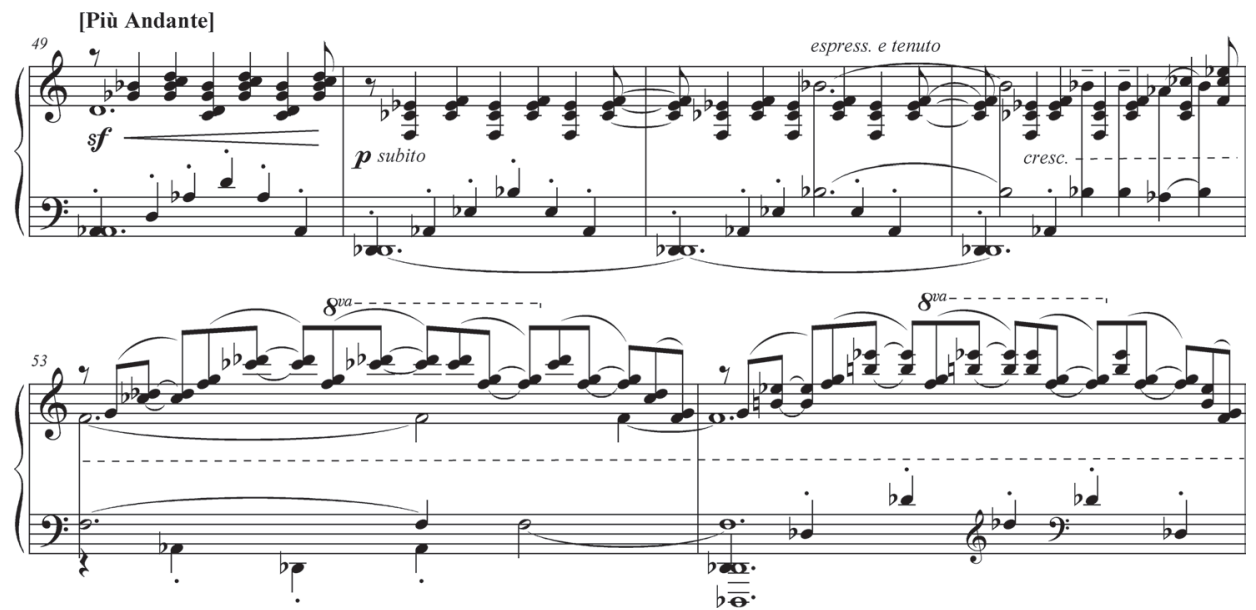

Example 1d Kodály, Méditation, mm. 63-69

Con moto

$8^{\text {va }}$

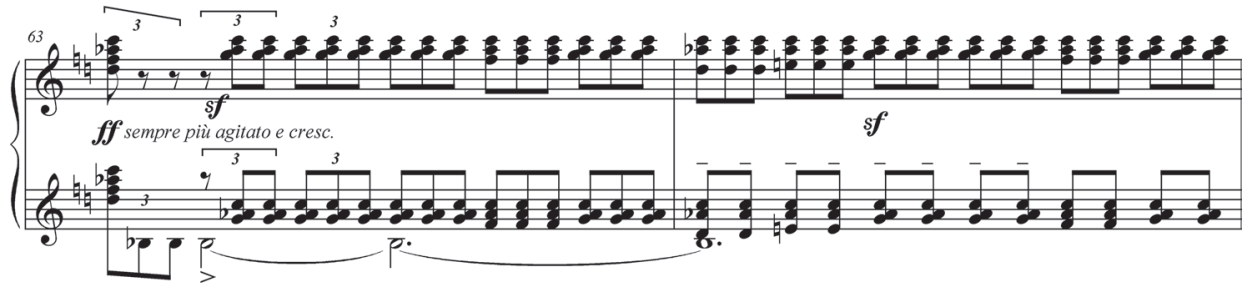

$8^{n a}$
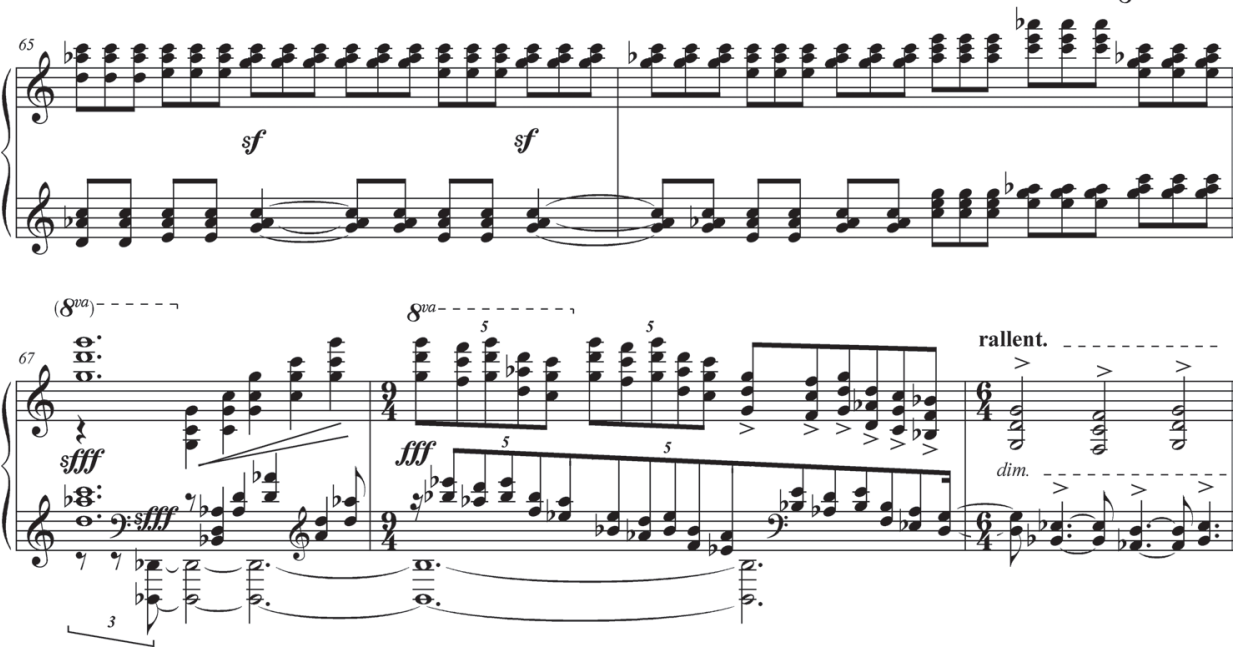
Kodály's title expresses his reverence for Debussy, which was not a usual thing to do in those days, as François Lesure remarks, calling it "hommage unique dans le monde à cette date." ${ }^{\prime 7}$ But how is Debussy's music represented in this basically Lisztian piece? The motif that is subjected to the Méditation derives from the String Quartet that is considered today an early composition of minor importance. The choice Kodály made is no obvious one. If it had been just an act of politeness to a famous colleague or an attempt to bring profit from his renommée to the own standing, Kodály could have chosen a slice of Pelléas or L'après-midi d'un faune. What made him choose the quartet?

Debussy's String Quartet of $1892-1893$, premièred in $1893,{ }^{8}$ is popular today with people who attend string-quartet recitals, because it seems to follow the paths of tradition. (Actually there are connections with Edvard Grieg's string quartet.) But at a performance given on 1 March 1894 in Bruxelles, at a time when the avant-garde in literature and arts flourished in the city, the audience was spellbound by a touch of otherness that they discerned, an inkling of non-Western music. At least Maurice Kufferath said so in a review of the recital. ${ }^{9}$

So, the piece Kodály takes as point of reference for his Méditation is not a conventional document of impressionism or of French style à la mode. Kodály's understanding of Debussy's poetics goes deeper. There is a special relationship between French music and the young Hungarian composers, who are, as Debussy puts it in an interview, "très proches de nous." ${ }^{10}$ After his visit to Budapest in December 1910, Debussy spoke of how these composers' "enthousiasme a quelque chose de français, qui nous les rend plus immédiatement sympathiques que nos soi-disant frères latins." ${ }^{11}$ And he sees the young composers in Budapest as much less conservative than their counterparts in Vienna. ${ }^{12}$

That Debussy's String Quartet sounds different and alien to the German-Austrian tradition of chamber music is partly due to its forme cyclique. The procedure is familiar from César Franck's Symphony in D minor and his Sonata in A major for violin and piano. The crucial point in the forme cyclique is a second level of thematic activity beside the traditional motivic/thematic development within a single movement. The new kind of thematic activity lies on top of the level of a single movement in a sonata cycle. There are themes that appear first quite early in the sonata cycle, but only when they reappear in the finale are they totally integrated

7. François Lesure, Claude Debussy. Biographie critique (Paris: Fayard, 22003), 331. See also pages 383-384 on Debussy, Kodály, Bartók, and Wagner.

8. Dedicated to the Quatuor Ysaÿe, it was premièred by them on 29 December 1893 at a concert mounted by the Société nationale de musique. Cf. Lesure, Claude Debussy, 518.

9. Léon Vallas, Claude Debussy et son temps (Paris : Albin Michel 1958), 175-176.

10. Interview with Michel-Dimitri Calvocoressi, "An Appreciation of Contemporary Music: Claude Debussy,” The Etude 32/6 (June 1914), 407; quoted in Lesure, Claude Debussy, 383.

11. Lesure, Claude Debussy, 331.

12. Ibid. 
into the musical narrative. In a way they are deficient initially, insofar as they are complete in themselves, but not adapted to their setting. And finally, when they reappear, there is not only adaptation, but fusion and mutual support, a real love feast between theme and form. The transformation happens without the effort and labor of thematic work, without reason, so to speak, as if by witchcraft or as a miracle.

The motif Kodály picks from Debussy's quartet is just one such witchcraft instance and does not behave in the way motifs would do in the German-Austrian tradition. It is among those partisans of music that do not respect borders of movements or rely on "serious" thematic work.

To summarize the comments here on Kodály's piano piece Méditation: this is non-discursive, instrumental music based on an interplay of structure and texture. It represents the Liszt-French tradition as a genuine constituent of Musical Modernism.

\section{Nine Piano Pieces, op. 3}

The piano pieces op. 3 pursue the concept of non-discursive music in different ways, with emphasis on different aspects. No. 4 is of special importance as the piece stresses the haptic dimension of music (Example 2).

Its starting point is neither a theme nor a structure, but pianistic play with intervals. It is fun to do. The two hands interlock closely in a way that asks for a maximum of agility. The texture in no. 4 is on the rudimentary side compared with the elaborate melody and accompaniment of op. 3 no. 3 or of Méditation sur un motif de Debussy: just a fifth as a framing interval and thirds to fill or palpate the area. There are no traces of singing or melody anywhere.

The musical material is neither invented (in an emphatic sense) nor deeply felt; it does not represent or express anything, but is found by exploring the "topography" of the instrument. ${ }^{13}$ The music has not been mentally preconceived before rendering it audible on an instrument (as Busoni sometimes strangely described the act of composition). ${ }^{14}$ It comes from treating the instrument as an organeobstacle, to borrow Jankélévitch's expression. ${ }^{15}$

Technical similarities to procedures common in music in later twentieth-century decades cannot be overlooked. The interval of a second in measures 3-4 is somehow hidden or kept latent. It moves more into the foreground in $\mathrm{m}$. 6 , and

13. The expression Landschaft (lit. landscape) des Instruments is Martin Widmaier's: Zur Systemdynamik des Übens. Differenzielles Lernen am Klavier (Mainz: Schott, 2016).

14. Ferruccio Busoni, Entwurf einer neuen Ästhetik der Tonkunst, hrsg. Hans Heinz Stuckenschmidt (Frankfurt am Main: Insel-Verlag, 1974), 29.

15. Vladimir Jankélévitch, Le Je-ne-sais-quoi et le Presque-rien vol. 2: La Méconnaissance - Le Malentendu (Paris: Seuil, 1980), 72. The concept goes back to the first chapter of Bergson's L'évolution créatrice. Cf. Henri Bergson, 0euvres (Paris : PUF, 1959), 575. 
Example 2 Kodály, Nine Piano Pieces, op. 3, no. 4, mm. 1-14
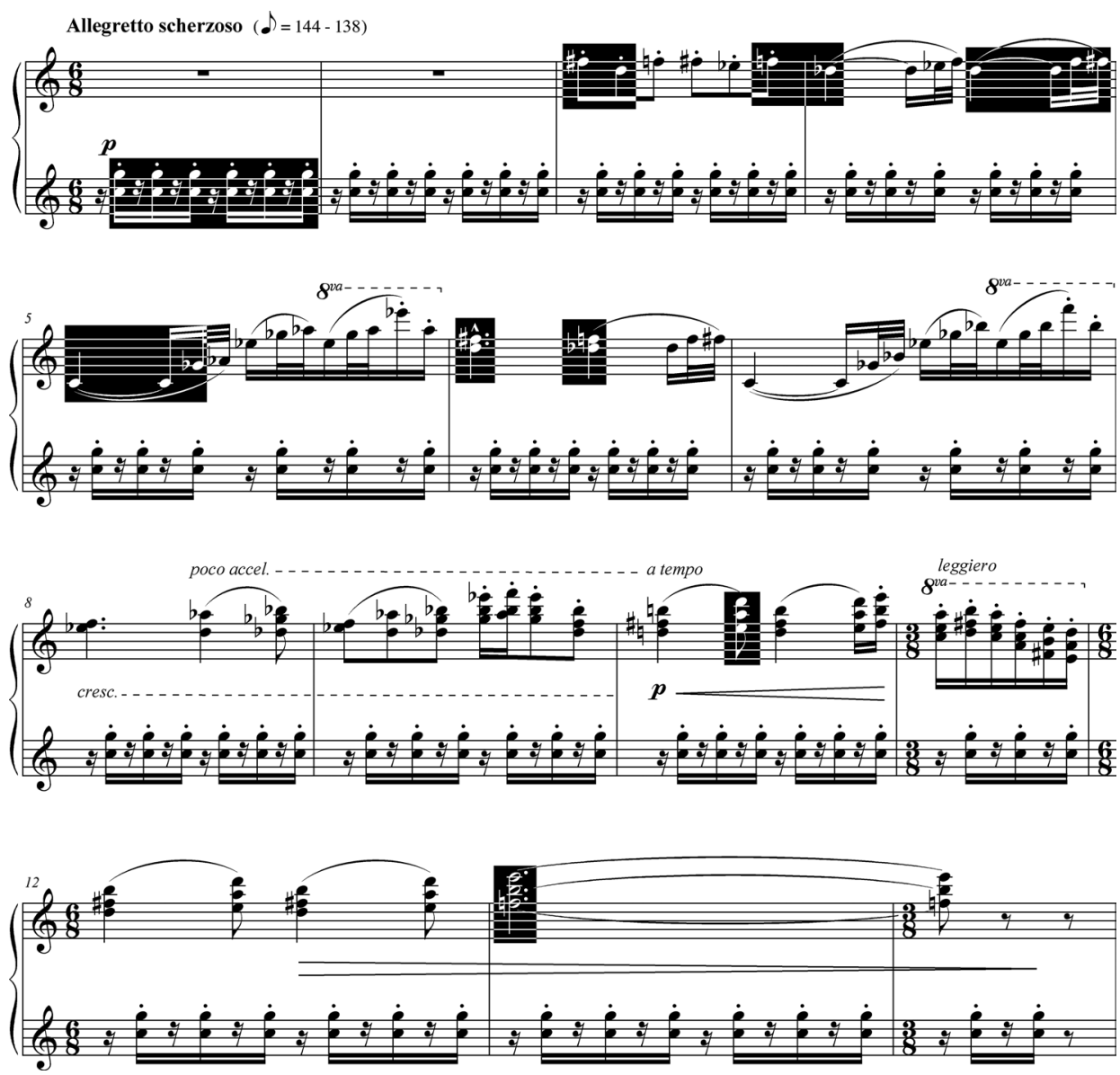

so on. The interval of a fourth is introduced as a signal highlighting the upper register. It piles up into chords of a fourth, as in $\mathrm{mm}$. 9-14. This is fun not only to play but to analyze: the material develops very systematically. (The middle section builds on fourths and fifths. Measure 24 starts a return to thirds. The coda plays with the thirds/fourths difference, taking up what was heard in measure 4.)

The first piece in the op. 3 collection differs from the third in having a melodic surface, but despite being melodic, the piece notably works in the same way as the one discussed before. The melodic (or declamatory) voice is part of an instrumental construction music (Example 3). 
The piece is in two analogous sections, both using the same series of interlocking fifths. The texture rests on a model of accompaniment and melody. The register and interaction of melody and accompanying repetition change during the piece, with the surface variations affecting the inner relation of the components.

Initially the upper part is just a gesture, recognizable only by two topoi: a falling second that forms a sigh motif (m. 4) and a falling third in a metric position

Example 3 Kodály, Nine Piano Pieces, op. 3, no. 1
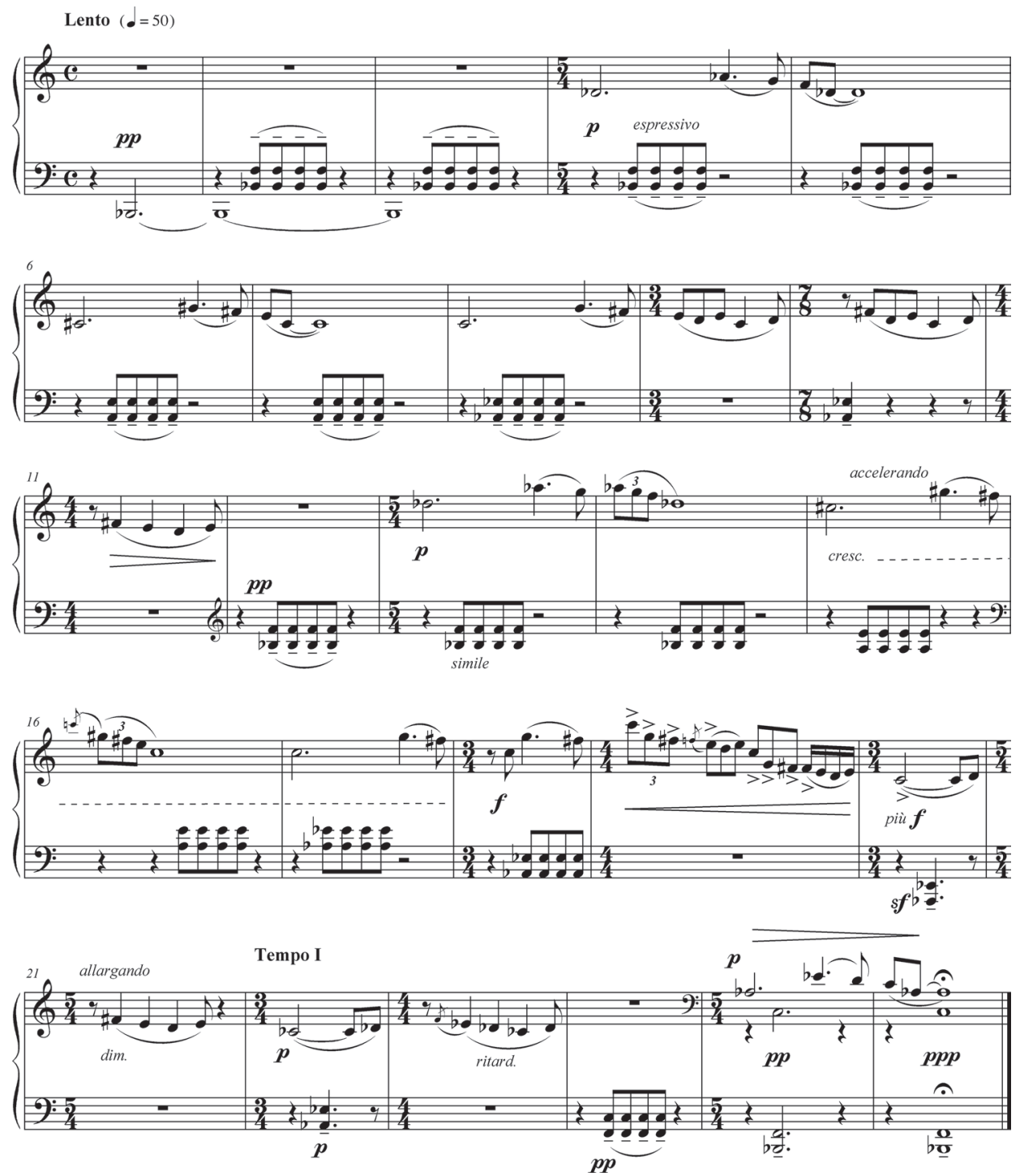
that gives a trochaic rhythm (m. 5). In diastematic terms it is no more than a way to scan the space of a fifth stepwise.

More melodic features develop as closing formulae, serving to bring the syntactic unit to an end (mm. 9-11). The peak of self-contained melodic activity is achieved in the second part (mm. 17-20), where a wide-spanned declamatory line colors the framework of a $\mathrm{C}$ major triad. Underlying this melodically emphasized triad there is a fifth e-flat/A-flat (m. 18, forte) which at the very end of the piece reappears transposed to an upper register and as a direct result of the melodic activity. In a sense, this is the maximum, the high noon of melody-accompaniment-interplay.

\section{Seven Piano Pieces, op. 11}

Since around 1800, songs had been complex music in exactly the sense that Hoffmann and Nägeli developed in their comments on the autonomy of instrumental music. ${ }^{16}$ And it is not just that the instrumental principle applies to songs as well. It can even be argued that a song is a good deal more complex than an instrumental piece.

Taking Beethoven's Kennst du das Land? as an example, ${ }^{17}$ the song starts with a kind of elaborate declamation wholly determined by the words, the motto question. Then it turns to music more reminiscent of chamber music. So the song includes and integrates different kinds of music. Being based on differences, driven forward by "différance" (written with a silent Derrida "a"), is the central principle of self-contained music that Hoffmann and Nägeli unfolded, referring to the paradigm of instrumental music.

Kodály, in his piano piece op. 11 no. 2 (Székler Klage), has added the words to the declamatory part of his score, probably to ensure that the pianist observes the Rubato, parlando indication, giving the repeated notes the weight, duration, and color of their corresponding syllables and words (Example 4a). By adding text to the score of a piano piece, Kodály emphasizes the distance that separates the realm of singing from that of autonomous musical organization. How does he deal with this distance in the composition? Does he turn this outward distance into an inward difference in his piece?

16. Cf. Walther Dürr, Das deutsche Sololied im 19. Jahrhundert. Untersuchungen zu Sprache und Musik (= Taschenbücher zur Musikwissenschaft 97) (Wilhelmshaven: Heinrichshofen's Verlag, 1984); Miriam Roner, Zwischen „Volksthümlichkeit“ und „Idealität“. Hans Georg Nägelis Theorie der Musik als autonomer Kunst und gesellschaftlicher Praxis (PhD Diss., University of Bern, Switzerland, 2016). The book will be released in 2019 by Steiner (Stuttgart), as part of the series Beiträge zum Archiv für Musikwissenschaft.

17. Thomas Kabisch, "Verzweigungen und Scharniere. Beethoven liest und komponiert Goethe," in Jahrbuch Musik in Baden-Württemberg, Bd. 9 (Stuttgart: Metzler, 2002), 150-164. 
Example 4a Kodály, Seven Piano Pieces op. 11 no. 2, Székely keserves, mm. 1-5

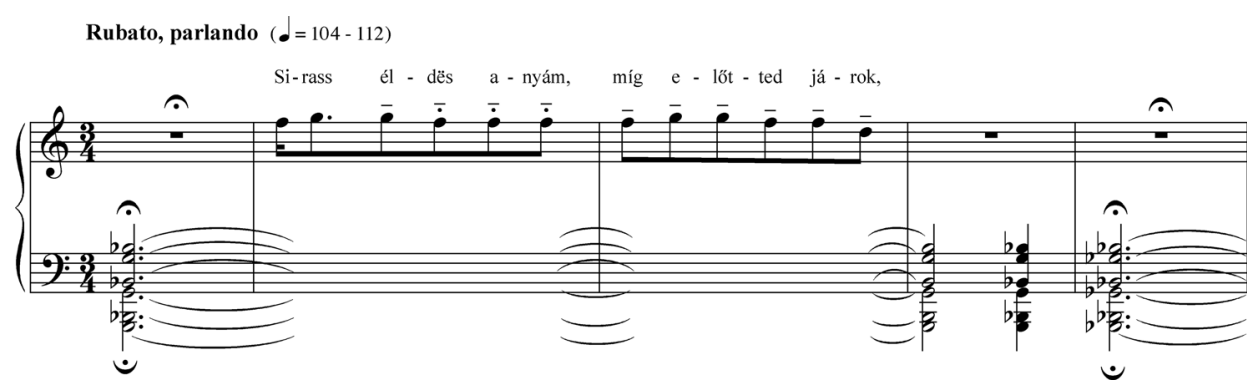

EXAMPLe 4b Kodály, Székely keserves, mm. 12-21
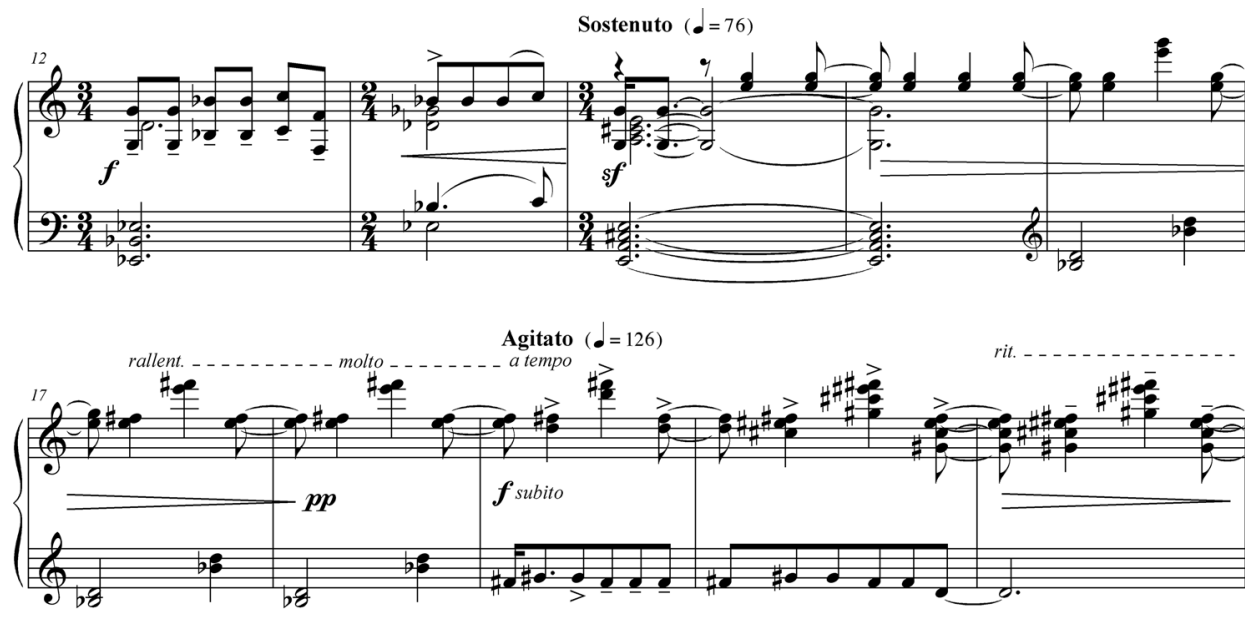

molto espr. e sempre marcato

I do not see such an attempt. Kodály wants the piano piece to act as a kind of frame for the words, not the words to become part and material of the piece as they do in Beethoven's song just mentioned.

No doubt the piece is in a sense structurally organized. The three sections matching the three stanzas use pentatonic groups in different transpositions (mm. 1-14: $\mathrm{f}^{2}-\mathrm{g}^{2}-\mathrm{b}-$ flat $^{1}-\mathrm{c}^{2}-\mathrm{d}^{2}$; m. 19: f-sharp ${ }^{1}-\mathrm{g}$-sharp ${ }^{1}-\mathrm{b}-\mathrm{c}-$ sharp $^{1}-\mathrm{d}-$ sharp $^{1} ; \mathrm{m}$. 33: like m. 1). There is another in the coda (m. 42: G-A-C-D-E). Between the first and second transpositions (Agitato, m. 19) comes a passage (Sostenuto, m. 14) that leads gingerly from the earlier $\mathrm{f}^{2}-\mathrm{g}^{2}$ to the discriminating $\mathrm{f}$-sharp $\mathrm{p}^{1}-\mathrm{g}$-sharp $\mathrm{p}^{1}$, as a bridge, but not as a transition in the true sense (Example $4 b$ ). Kodály builds a bridge and concurrently demolishes it. He seeks sharp contrast. The second part breaks out (m. 19) in a faster subito forte, after the previous music has died away in pianissimo and rallentando molto (m. 17-18). The same effect appears much more drastically at the start of part three (m. 33, see Example 4c). 
ExAmPLE 4c Kodály, Székely keserves, mm. 31-43

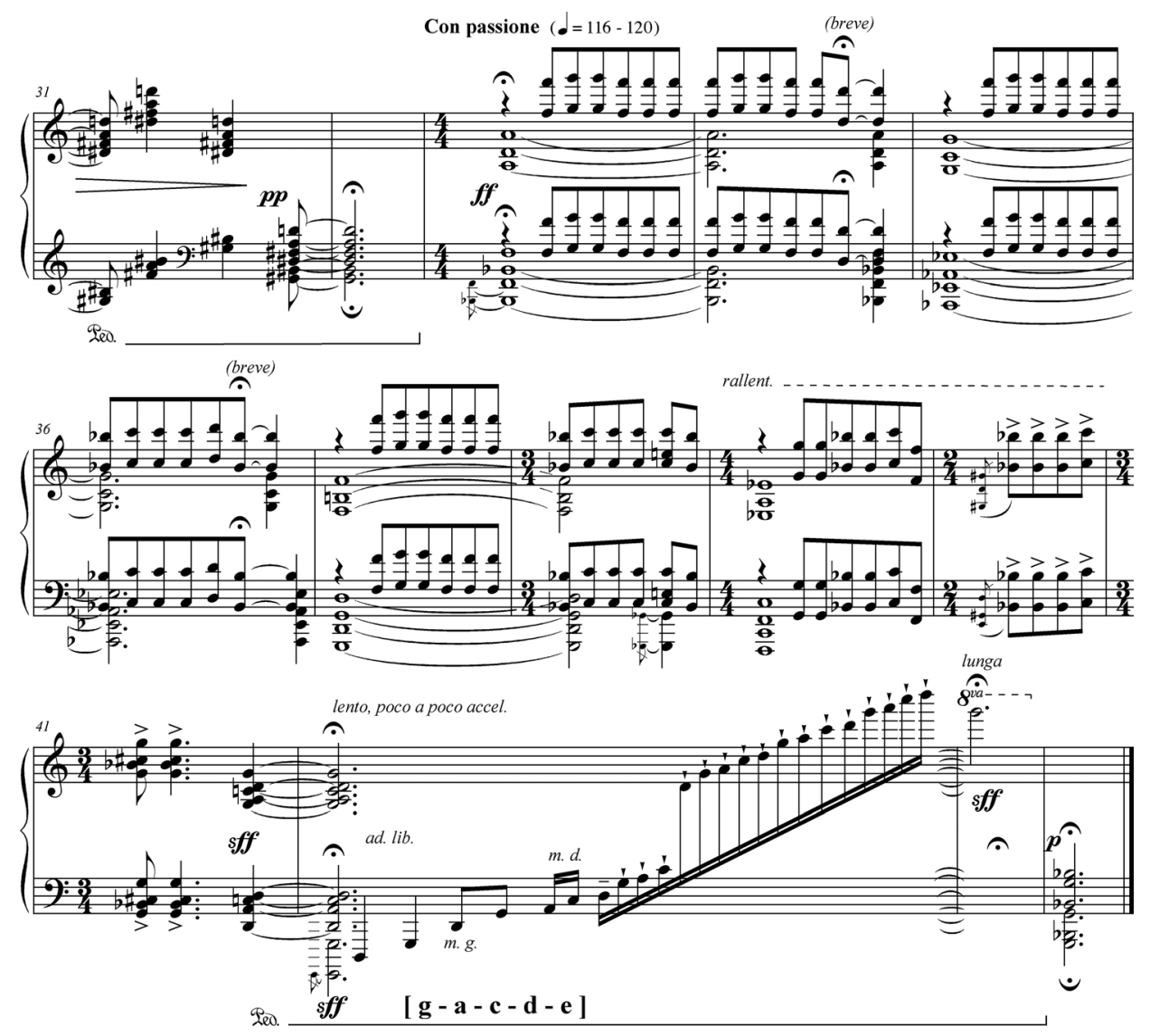

Kodály's aim is intensification. He then brings out three ways of declamation supported and framed by music. He does not want the words to be composed, absorbed, or digested by the music. He is not writing an art song without words. He tries to be faithful to "natural" singing (so to speak) as a direct form of self-expression. This becomes clear in the third stanza, when the melody is hammered out in double octaves. Yet this texture is unconvincing as a way of partitioning music on a piano: Kodály in his composition proves the instrument incapable of achieving what he sees as the one adequate way of expressing the lament. He composes against the instrument and gains expression by exceeding its limits. His piece is an instrumental image of singing, portrayed in the failed attempt to replace it by a piano. 


\section{Musical Modernism - once more}

Kodály's break with the principles of instrumental music was no sudden one and did not occur as late as 1923. His critique of instrumental music becomes manifest not only in changing genres, in switching from instrumental to choral composition. His piano pieces op. 11 challenge the principles of instrumental music within its own realm. In terms of aesthetic achievement op. 11 is - to say the least - less convincing than op. 3. Nor do the pieces in op. 11 qualify as a model or provide a solid base for composing in the future.

Is it by chance that the piano pieces of op. 11 miss the mark, or should they be seen and judged within the context of Kodály's musical poetics, as a first step that eventually led him to his vocal/national/pedagogical project, a development from elitist to populist views, from compositional research to music as communication, so taking up some of the binary oppositions Richard Taruskin uses as reference points in his picture of twentieth-century music? ${ }^{18}$

This paper has argued there is way out of the dilemma of damnation for aesthetic reasons and apology for social and moral reasons. My proposal is to discuss Kodály's pieces in the context of Musical Modernism, i.e. of an epoch whose protagonists have been dealing with the aesthetic foundations and compositional means of Classical-Romantic music, in a manner that can roughly be denoted as mannerist. Musical Modernism gives stress tests to the classical foundations of music. Seeking problems rather than solutions, they put up with the lack of achievement in single works, a price to be paid for insights into the fundamentals of music.

Kodály's op. 11 takes risks generally characteristic of those taken by composers of Musical Modernism. His critical exploration of instrumental music reveals how autonomous music works and why we would be ill-advised to exclude it for social or moral reasons, even though Kodály himself did so, looking back some decades later.

Autonomous instrumental music developed concomitantly with the split between high culture and lowbrow music, but the two historical developments should not be amalgamated as "elite music". Musical Modernism basically means a reflective, analytical approach to both the aesthetic and the technical features of the classical paradigm. So there is no compelling reason for musicologists to follow Kodály's self-interpretation or condemn the rationality of instrumental music to express sympathy with the humiliated and insulted.

The anathema "elite music is socially divisive," advanced by Richard Taruskin in his keynote on Kodály at the conference in Budapest, echoed Kodály's later

18. Richard Taruskin, The Oxford History of Western Music, vol. 4: The Early Twentieth Century (Oxford University Press, 2005). 
views on music and society (and may reflect the present situation in the United States). But it does not follow from what Kodály did in his op. 11. Other musicians deeply emerged in social questions of music, such as the German composer Hanns Eisler or the analyst and music writer August Halm insisted on the social function of autonomous music. They did not blame instrumental music, but the social structures for the gap between the rich potential of musical expression and the restricted receptivity and responsiveness of a broad public. They did not slam vocal music at the expense of instrumental. They sought ways to free music from its social constrictions.

In short, they took the discriminatory and differential efforts achieved in Musical Modernism as a starting point for projects in music pedagogy (Halm) and political music (Eisler), while Kodály in later years tended to ignore the insights he had gained through Musical Modernism and replace them with an idea of unmediated unity of music, nation, and pedagogy. 